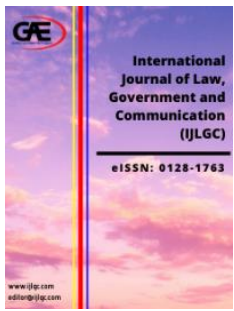

\author{
INTERNATIONAL JOURNAL OF LAW, \\ GOVERNMENT AND COMMUNICATION \\ (IJLGC) \\ www.ijlgc.com
}

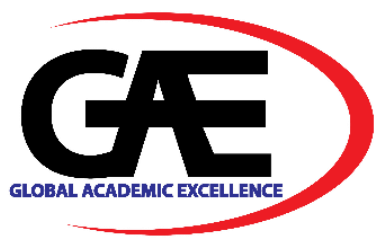

\title{
ANTI-MONEY LAUNDERING AND ANTI-TERRORISM FINANCING OBLIGATIONS FOR THE MONEY SERVICES BUSINESS IN MALAYSIA: AN APPRAISAL
}

\author{
Raja Madihah Raja Alias ${ }^{1 *}$, Norhashimah Mohd Yasin ${ }^{2}$ \\ $\mathrm{PhD}$ (Law) Candidate, Ahmad Ibrahim Kulliyyah of Laws, International Islamic University Malaysia. \\ Email: rajamadihah.rajaalias@gmail.com \\ 2 Civil Law Department, Ahmad Ibrahim Kulliyyah of Laws, International Islamic University Malaysia. \\ Corresponding Author
}

Article Info:

Article history:

Received date: 18.10 .2021

Revised date: 14.11 .2021

Accepted date: 15.12 .2021

Published date: 23.12 .2021

\section{To cite this document:}

Raja Alias, R. M., \& Yasin, N. M. (2021). Anti-Money Laundering And Anti-Terrorism Financing Obligations For The Money Services Business In Malaysia: An Appraisal. International Journal of Law, Government and Communication, 6 (26), 159-167.

DOI: $10.35631 / I J L G C .626014$.

This work is licensed under $\underline{\text { CC BY } 4.0}$

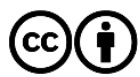

\begin{abstract}
:
The money services business (MSB) is a financial institution comprising money-changing business, remittance business and wholesale currency business. As a financial institution, the MSB is subjected to the anti-money laundering and counter financing of terrorism (AML/CFT) requirements in Malaysia. Thus, the objective of this article is to examine the AML/CFT legal requirements to the MSB sector in Malaysia. This study employed doctrinal legal research by analysing the primary and secondary legal sources. Thus, this study analyses the importance of AML/CFT preventive measures, which are (i) risk-based approach; (ii) customer due diligence; (iii) record-keeping; (iv) suspicious transaction report; and (iv) AML/CFT compliance programme. Despite the AML/CFT statutory obligations, the study found that the MSB is at high risk for these crimes due to the lack of AML/CFT compliance. Thus, having continuous compliance and rigorous enforcement by authorities is necessary for combating these organised crimes.
\end{abstract}

Keywords:

Money Services Business; Money Laundering; Terrorism Financing

\section{Introduction}

Combating money laundering and terrorism financing (ML/TF) is crucial to ensure financial stability in a country. The criminals use a wider range of methods to conceal the dirty money and integrate the funds into a licit transaction (Jojarth 2014). Due to its significance, strong political will in a country is the most effective in combating these financial crimes (Durner and Cotter 2018). Thus, the government must be committed to enacting the legislation and taking preventive measures to deter ML/TF risks.

Copyright (C) GLOBAL ACADEMIC EXCELLENCE (M) SDN BHD - All rights reserved 


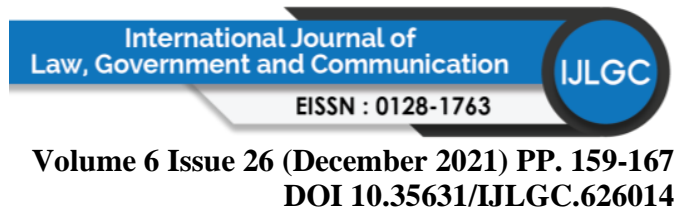

In Malaysia, the Malaysian government has committed to take legislative efforts in combating the ML/TF activities in the country. In 2001, the Anti-Money Laundering Act 2001 (Act 631) (AMLA) was the first governing law combating ML/TF. Later in 2007, the AMLA was further amended as Anti-Money Laundering and Anti-Terrorism Financing Act 2001 (Act 631) (AMLATFA) by adding Part VIA for the offences on suppression of TF and power to freeze, seizure and forfeit the terrorist property. Then, in 2014, the AMLATFA was further amended to Anti-Money Laundering, Anti-Terrorism Financing and Proceeds of Unlawful Activities Act 2001 (Act 631) (AMLATFPUAA) by adding the provisions on the proceeds of unlawful property that have been derived directly or indirectly for the commission of unlawful activity. In protecting the financial and non-financial institutions in the country, the First Schedule of the AMLATFPUAA has listed the list of Reporting Institutions that are required to comply with the AML/CFT preventive measures. The purpose of these statutory obligations is to prevent their institutions from being used as a conduit for ML/TF activities. In this respect, the money services business (MSB) is one of the Reporting Institutions that has been listed under the First Schedule of the AMLAFTPUAA and required to comply with the AML/CFT preventive measures.

Nevertheless, despite statutory obligations, the recent report on "Proliferation Financing Risk Assessment 2021" issued by the Bank Negara Malaysia (BNM) has stated that the MSB is vulnerable to these financial crimes risks (Bank Negara Malaysia, 2021). Among the risk factors are the purpose of transactions, the high risk of the customer, and transactions value, products or services offered. Additionally, the recent Annual Report 2020 published by the BNM also stated that there are 6 convictions for the offences related to ML/TF activities, amounting to fines of RM1.3 million and imprisonment for the offenders (Bank Negara Malaysia 2020).

Therefore, this paper seeks to examine and analyse the statutory obligations in compliance with the AML/CFT preventive measures to the MSB sector in Malaysia. The significance of this paper is to enrich existing literature on AML/CFT compliance related matters. The article is limited to AML/CFT preventive measures under Part IV of the AMLATFPUAA and the Policy Documents and Guidelines issued by the BNM up until October 2021. Thus, this paper begins with a background to the MSB sector in Malaysia. This paper further continues on the concept of ML/TF and the legal requirements imposed on the MSB in Malaysia. This paper ends with the recommendations and conclusion to ensure AML/CFT compliance for the MSB sector in Malaysia.

\section{Money Services Business Sector in Malaysia: A Development}

Money-changing and remittance services are one of the oldest methods of currency payment systems. History shows that the money changers were the earliest institution of finance that set the economic causes for the rise of the bill of exchange and later led to the opening of the banking system (W. S. Holdsworth 1918). Some prominent companies, such as the Western Union, MoneyGram, and PayPal, are the common currency exchange institutions to facilitate the customers exchanging or transferring the money by not using the banking institutions.

In Malaysia, the currency exchange and remittance services are governed under the Money Services Business Act 2011 (Act 731) (MSBA). The Preamble of the MSBA elucidates the purpose of enacting this legislation to provide for the licensing, regulation and supervision of 


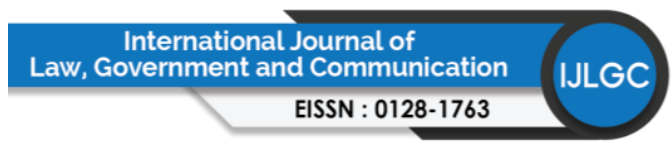

Volume 6 Issue 26 (December 2021) PP. 159-167

DOI 10.35631/IJLGC.626014

MSB. In addition, among the objectives of the MSBA is to transform the financial system towards more efficient and cost-effective remittance and currency exchange services. Also, this Act was introduced to have a dynamic, competitive and professional financial industry and to safeguard against any illegal activities.

Before 2011, the money-changing business was governed under the Money-Changing Act 1998 (Act 577) and the Exchange Control Act 1953 (Revised 1969) (Act 17) for the remittance and wholesale currency business. Then, to further strengthen this financial institution, the MSBA was introduced to ensure professionalism, AML/CFT compliance and customer protection.

Presently, the MSB activities comprise 3 categories as follows:

i. Money-changing business. A money-changing business is a currency exchange transaction based on the exchange rate. A money-changing is also known as currency exchange, money exchange, or bureau de change in the French language. Section 2 of the MSBA defines money-changing business as the exchange transaction at an exchange rate and business of buying or selling travellers' cheques.

ii. Remittance business. A remittance business refers to the business of transferring funds or facilitating the transfer of funds.

iii. Wholesale currency business. The wholesale currency business refers to buying or selling foreign currency or importing foreign currency notes.

Section 4 of the MSBA states that the MSB should possess a license before operating the business. In this relation, any person operating the MSB without a valid license commits an offence. Upon conviction, an offender will be liable to a fine not exceeding RM5 million or to imprisonment not exceeding 10 years. Section 5 of the MSBA states that the application for a license shall be made by making a written application to the BNM. The license is valid only for 3 years and requires further renewal.

Thus, the above shows the development and legal practices of the MSB sector in Malaysia. A subsequent section further provides the conceptual and international requirements of AML/CFT relevant to the MSB sector in Malaysia.

\section{Money Laundering and Terrorism Financing: Conceptual and International Requirements}

The ML/TF are contemporary crimes that have been codified as criminal offences in many jurisdictions. The ML is a process to disguise the source of the property obtained from illegal activities. The expression of ML is not new and appeared in the 1920s when the famous gangster Al-Capone had opened the laundries business that recorded as legally earned money to conceal the origin of criminally obtained property (Hotca 2015). The ML also happens when the criminal generates a huge amount of unlawful property and the criminal conceal the illegal sources or moving the funds into any financial or non-financial institutions to disguise the origin of the money (Norhashimah \& Mohd Yazid, 2018).

Meanwhile, the concern on combating TF emerged after the 11 September 2001 attacks in the United States of America (USA). The international organisations have urged all the countries to criminalise the TF offences to any person providing the funds to terrorist organisations or individuals to commit terrorist activities. The person also has used various methods to commit 


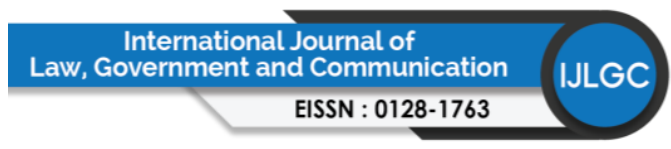

Volume 6 Issue 26 (December 2021) PP. 159-167

DOI 10.35631/IJLGC.626014

TF offences. According to Mullins \& Wither (2016), the arms dealers, smugglers, money launderers, purveyors of false documents and corrupted officials are the common networks for the terrorists to commit terrorism. Also, TF can be utilised through many channels, such as funding through legitimate income, non-profit organisations, social media, crowd-funding, and criminal activity (Santoso and Laksmi 2016). Contrary to ML, the terrorists raise funds from legal and illegal channels to support the terrorists (Durner and Cotter 2019). For ML, its origin is from illegitimate sources, and meanwhile, the TF sources can be from lawful or unlawful sources that channel terrorist funds for terrorist activities (Tofangsaz 2015). Regardless of its origin, ML/TF are the financial crimes that will damage financial stability in the country. Thus, international organisations and the local jurisdiction should criminalise these financial crimes to protect the integrity and financial institutions in the country.

International efforts also have urged all the jurisdictions to criminalise ML/TF offences. The United Nations (UN) commenced the first efforts to criminalise ML in 1988. In this relation, the UN has convened the first United Nations Convention against Illicit Traffic in Narcotics Drugs and Psychotropic Substances ("Vienna Convention") to criminalise ML through drug trafficking offences. This Vienna Convention aims to prevent the entrance of crime proceeds into the legitimate economy (Korejo, Rajamanickam, and Muhamad 2021). This Vienna Convention also reflects the response from an international community due to illicit crimes related to drug trafficking offences and ML activities (Vanni 2015). Due to its significance, all the countries are required to ratify this Vienna Convention. Malaysia has signed the Vienna Convention on 20 December 1988 and ratified 11 May 1993 to show its commitment to combating ML/TF crimes.

Also, the Financial Action Task Force (FATF) was established in 1989 in ensuring all the countries adopted the international standards in combating these financial crimes. The FATF is an inter-governmental body established to combat ML/TF, financing of proliferation and other related threats to the integrity of the international financial system. In 1990, the FATF had issued the first international standards, the Forty Recommendations to combat ML. After the 11 September 2001 terrorist attacks, the FATF expanded to the Nine Special Recommendations on TF. Then, in February 2012, the Forty Recommendations and Nine Special Recommendations merged as Forty Recommendations to strengthen and ensure the integrity of the financial systems in combating ML/TF and become an international standard for the AML/CFT measures in all over 180 countries.

Thus, compliance with AML/CFT international measures is crucial for a country and financial institutions. As a member of the UN since 17 September 1957, Malaysia has committed to complying with the international obligations required by the UN. Also, Malaysia has become a member of FATF since 2016. Malaysia has updated the legislation to comply with the AML/CFT international standards in combating the ML/TF crime in the country. Therefore, the subsequent section will further examine the AML/CFT legal compliance for the MSB based on the international requirements as Malaysian law and policies.

\section{AML/CFT Legal Compliance for the Money Services Business}

Legal compliance can be defined as a set of processes and procedures to ensure adherence to governing laws and regulations (Claydon 2013). The importance of compliance is to mitigate any risk, enhance the value, and prevent any violations and misconduct (Martin 1997). Also, 


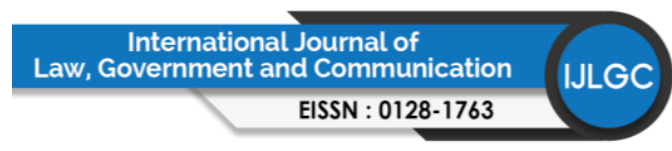

Volume 6 Issue 26 (December 2021) PP. 159-167

DOI 10.35631/IJLGC.626014

compliance is crucial to ensure there are no financial losses, operational risks, and any legal action that will be taken in the event of non-compliance.

In this respect, the MSB, as one of the Reporting Institutions under the AMLATFPUAA required to comply with the AML/CFT preventive measures under the Act. Section 22 of the AMLATFPUAA provides that any non-compliance shall be liable to a fine not exceeding RM1 million ringgit or to imprisonment for a term not exceeding 3 years or to both. In the case of continuing offence for non-compliance, section 22 further states that a fine not exceeding RM3000 for each day continues if a continuous offence is committed. The risk of noncompliance is on monetary and imprisonment sentencing and might pose the MSB as a high risk for ML/TF activities. In the case of Dahabshill Transfer Services Ltd v Barclays Bank plc; Harada Ltd and another $v$ Barclays Bank plc, the court stated that it is common ground that the MSB sector is a high-risk industry that needs to be subjected to AML/CFT regulation. Thus, it is pertinent for the MSB to observe and adhere to AML/CFT preventive measures requirements. The 5 main AML/CFT preventive measures that need to be complied with by the MSB are as follows:

i. Risk-based approach

ii. Customer due diligence

iii. Record-keeping

iv. Suspicious transaction report

v. AML/CFT compliance programme

\section{Risk-Based Approach (RBA)}

The risk-based approach (RBA) is required for financial institutions to identify and measure any possibility of ML/TF risks in their institutions. Thus, the regulator, law enforcement and all the Reporting Institutions including the MSB must respond to RBA to mitigate any potential ML/TF activities (Ross and Hannan 2007). Recommendation 1 of the FATF provides that the institution needs authority or a mechanism to mitigate the risks effectively. Thus, a country is required to apply the RBA even though the ML/TF risks are low and provide the resources for persons and activities to comply with RBA requirements (Koker 2009).

In Malaysia, all the Reporting Institutions including the MSB should comply with the latest "Anti-Money Laundering, Countering Financing of Terrorism and Targeted Financial Sanctions for Financial Institutions" ("Policy Document") issued by the BNM for guidance in conducting the RBA. The Policy Document provides that the RBA measures should consider all the relevant risk levels and update the documentation during the process. The RBA system must consider all factors, such as the transactions, customers, and the attractiveness of channels to conduit the money laundering and terrorism financing activities (Levi and Reuter 2006). In this relation, RBA is crucial for the MSB to measure and identify any risks to their customers and transactions. It is essential to detect potential ML/TF risks and take appropriate measures based on the risk levels.

\section{Customer Due Diligence (CDD)}

Customer due diligence (CDD) or the "Know-Your-Customer" process is vital for preventing ML/TF (Demetriades, 2016). This CDD requirement expected the financial institutions to understand their customer in-depth and assess any ML/TF risks associated with a customer (Shust and Dostov, 2020). Recommendation 10 of the FATF Forty Recommendations provides that financial institutions should be required to undertake CDD measures when establishing 


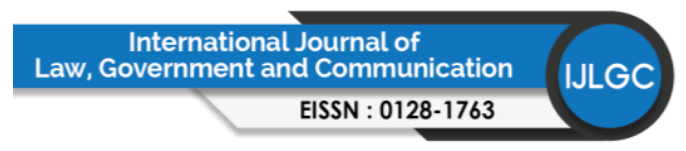

Volume 6 Issue 26 (December 2021) PP. 159-167

DOI 10.35631/IJLGC.626014

business relations and have any ML/TF suspicions or doubts about the veracity or adequacy of customer identification data.

In addition, Section 16(1) of the AMLATFPUAA requires that a Reporting Institution undertake not to operate any anonymous account and not establish or conduct a business relationship that is fictitious, false or incorrect. Also, the Reporting Institution shall maintain the customer's accounts and record customer details, transactions, or activity. Then, Section $16(2),(3) \&(4)$ further requires that the measure shall be taken, particularly when establishing and conducting transactions with the customers and when there is suspicion of the ML or TF offences. Moreover, the Policy Document requires that the MSB conduct the CDD requirements when the minimum of transactions is above RM3,000. Thus, the MSB is required to obtain certain documentation such as the official identifications to conduct the CDD measures.

In this relation, the CDD requirement is a measure that requires the MSB to identify the account holder when establishing the business relationship with the customer. The CDD or KYC practice begins when an individual or company applies to open an account or conduct the transactions (Norhashimah, 2007). Thus, conducting CDD is crucial to protect from ML/TF risks and guard the business against any deception or malpractice during the transactions with the customer.

\section{Record-Keeping}

Recommendation 11 of the FATF Recommendations provides the requirement to maintain a customer's records on the transaction for at least five (5) years. Section 13 of the AMLATFPUAA requires the MSB to keep a record of any transactions with a customer. Section 17 further requires the MSB to retain the record for at least 6 years from the date the account is closed or upon the termination of transactions. The Policy Document requires the MSB to record the receipt of the transaction with the customer. In the case Armenia Scotts Properties (KL) Sdn Bhd v The Ascott Limited \& Others [2012] 1 LNS 487 (HC), the court emphasised the importance of record-keeping to the MSB sector. In this case, the court held that a money changer commits an offence under AMLATFPUA when not reporting suspicious transactions and keeping any records when conducting the transaction with the customer. The importance of record-keeping is also reiterated in the case of TC00085: Rory Trainor Trading as Best Rate Bureau [2009] UKFTT 117 (TC). The court held that compliance with the recordkeeping requirements is therefore of considerable importance and failure to comply is a serious matter deserving the imposition of a significant penalty.

\section{Suspicious Transaction Report}

Reporting any suspicious transaction is one of the crucial measures to identify any ML/TF risks and assist the authority take prompt actions in conducting the investigations based on the report. Thus, the Reporting Institutions are required to analyse the funds and transactions involved and promptly report to the authority if there is any suspicion during the commission of transactions (Le Nguyen 2018). The FATF Forty Recommendations provides that reporting a suspicious transaction shall be conducted when the financial institution has reasonable grounds to suspect that funds are the proceeds of criminal activity. In Malaysia, section 14 of the AMLATFPUAA requires that the Reporting Institutions promptly report to an authority whenever has reason to suspect the transactions with the customer have any ML/TF risks. In the case Ooi Meng Khin $v$ Amanah Scotts Properties (KL) Sdn Bhd [2014] 1 LNS 719, the court held that the money- 


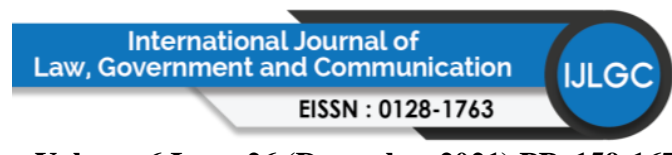

Volume 6 Issue 26 (December 2021) PP. 159-167

DOI 10.35631/IJLGC.626014

changer must report whenever to have any suspicious transactions. The court also held that the money changer has a duty of care that requires any reasonable money-changer to make reasonable inquiries if there is any suspicion during the transactions. Also, supported with the case of Lloyds Bank Ltd v EB Savoury \& Co [1933] AC 201, the court held that the institutions must apply a standard of "reasonable banker test". This standard is when the bank must take ordinary practice as a banker and it is not negligence when the bank has followed the precaution and responsibilities as required. Therefore, reasonable MSB is practised when MSB has taken all necessary measures and comply with all requirements to deter any ML/TF risks during the transaction with the customer.

\section{AML/CFT Compliance Programme}

A compliance programme is when an organisation should have appropriate procedures and policies to comply with AML/CFT requirements. Recommendation 25 of the FATF Forty Recommendations stated that an organisation must have adequate AML/CFT policies and procedures within an organisation. The purpose of this compliance programme is to ensure high standards of integrity in an organisation. The requirement also imposes a duty to superiors to have a system to evaluate employees' personal, employment, and financial history (Norhashimah \& Mohd Yasin, 2018).

Therefore, section 19(1) of the AMLATFPUAA provides a provision on the AML/CFT compliance programme. This section requires the Reporting Institutions including the MSB to implement internal programmes, policies and procedures to safeguard their organisation from ML/TF risks. Section 19(2) further requires the Reporting Institutions to evaluate their employees' personal, financial, and employment histories. Also, it is a duty where the employees need to be trained on AML/CFT preventive measures requirements, particularly in conducting the CDD, STR, and record-keeping measures. Additionally, an independent audit function has to check on the compliance programmes in the Reporting Institutions.

This requirement implies that all the personal in the Reporting Institution organisation play a role in deterring potential ML/TF risks. Understanding the statutory obligations under the AMLATFPUAA is a fundamental step to prevent any risks in their organisation. It is also crucial that all levels of staff need to update their knowledge and competencies to accomplish the statutory requirements as imposed by an international organisation and Malaysian legal frameworks. Therefore, all staff will perform their AML/CFT duties efficiently and help an organisation comply with the requirements of the preventive measures.

\section{Conclusion}

$\mathrm{ML} / \mathrm{TF}$ are heinous crimes and the MSB must ensure their vigilance and full compliance with the AML/CFT requirements. This study has shown the importance of AML/CFT compliance to the MSB sector in Malaysia to ensure the industry not expose to any ML/TF risks in their organisation. Malaysia also keeps updating its legislation to ensure compliance with international requirements and provide guidelines for industry to ensure AML/CFT compliance. This study is limited in examining the legal frameworks and providing crucial AML/CFT compliance for the MSB sector. Thus, further study on the compliance level to the MSB is necessary to enrich the findings on the AML/CFT compliance by the MSB sector. 


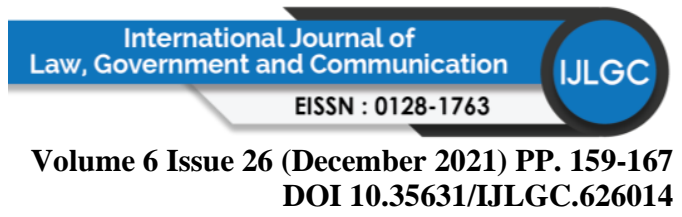

\section{References}

Anti-Money Laundering, Anti-Terrorism Financing and Proceeds of Unlawful Activities Act 2001 (Act 631)

Anti-Money Laundering, Countering Financing of Terrorism and Targeted Financial Sanctions for Financial Institutions (Policy Document)

Armenia Scotts Properties (KL) Sdn Bhd v The Ascott Limited \& Others [2012] 1 LNS 487 (HC)

Claydon, Jane (2013). “Compliance/Legal Compliance." in Encyclopedia of Corporate Social Responsibility, edited by S. O. Idowu, N. Capaldi, L. Zu, and A. Das Gupta. SpringerLink.

Dahabshill Transfer Services Ltd v Barclays Bank plc; Harada Ltd and another v Barclays Bank [2013] EWHC 3379 (Ch)

Demetriades, George (2016). "Is the Person Who He Claims to Be?' Old Fashion Due Diligence May Give the Correct Answer!" Journal of Money Laundering Control 19(1):79-91. doi: 10.1108/JMLC-11-2014-0041.

Durner, Tracey, and Danielle Cotter (2018). Considerations for AML/CFT Programming. Global Center on Cooperative Security.

Durner, Tracey, and Danielle Cotter (2019). Untangling a Marriage of Convenience AntiMoney Laundering and Countering the Financing of Terrorism.

Financial Action Task Force (FATF) Recommendations

Hotca, Mihai Adrian (2015). "Shall the Offender or the Participant in the Predicate Offense Be Held Criminally Liable If He / She Performs the Laundering of the Proceeds from the Committed Offense?” Journal of Eastern-European Criminal Law 1:99-106.

Jojarth, Christine (2014). "Money Laundering: Motives, Methods, Impact, and Countermeasures." in Transnational Organised Crime: Analyses of a Global Challenge to Democracy, edited by H.-B.-S. and R. Schönenberg. Columbia University Press.

Koker, Louis de. (2009). "Identifying and Managing Low Money Laundering Risk: Perspectives on FATF'S Risk-Based Guidance." Journal of Financial Crime 16(4):334-52. doi: 10.1108/13590790910993717.

Korejo, Muhammad Saleem, Ramalinggam Rajamanickam, and Muhamad Helmi Muhamad (2021). "The Concept of Money Laundering: A Quest for Legal Definition." Journal of Money Laundering Control. doi: 10.1108/JMLC-05-2020-0045.

Lloyds Bank Ltd v EB Savoury \& Co [1933] AC 201

Levi, Michael, and Peter Reuter (2006). "Money Laundering." Crime \& Justice: A Review of Research 34:289-376.

Malaysia, Bank Negara (2020). Bank Negara Malaysia Annual Report 2020.

Malaysia, Bank Negara (2021). "Proliferation Financing Risk Assessment." National Coordination Committee to Counter Money Laundering (August). Retrieved August 15, 2021 (https://amlcft.bnm.gov.my/document/PFRA_Report_Aug_2021.pdf).

Money Services Business Act 2011 (Act 731)

Martin, Jay G. (1997). "Implementing Effective Corporate Legal Compliance Programs." Natural Resources \& Environment 11(4):14-19.

Mullins, Sam, and James K. Wither (2016). "Terrorism and Organised Crime." Connections: The Quarterly Journal 15(3):65-82. doi: 10.11610/connections.15.3.06.

Norhashimah Mohd Yasin (2007). Legal Aspects of Money Laundering in Malaysia from the Common Law Perspective, LexisNexis Malaysia Sdn. Bhd.

Norhashimah Mohd Yasin and Mohd Yazid Zul Kepli (2018). Anti-Money Laundering and Counter Financing of Terrorism Law in Malaysia, LexisNexis Malaysia Sdn. Bhd. 


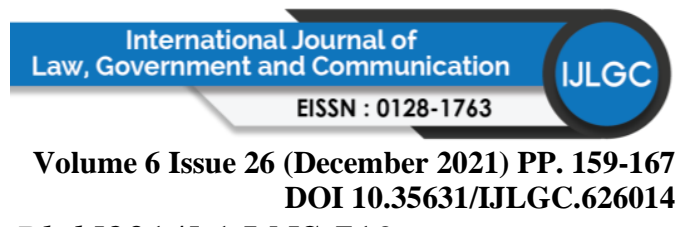

Ooi Meng Khin v Amanah Scotts Properties (KL) Sdn Bhd [2014] 1 LNS 719

Le Nguyen, Chat (2018). "Preventing the Use of Financial Institutions for Money Laundering and the Implications for Financial Privacy." Journal of Money Laundering Control 21(1):47-58. doi: 10.1108/JMLC-01-2017-0004.

Ross, Stuart, and Michelle Hannan (2007). "Money Laundering Regulation and Risk-Based Decision-Making." Journal of Money Laundering Control 10(1):106-15. doi: 10.1108/13685200710721890.

Santoso, Agus, and Syvia Windya Laksmi (2016). "Regional Terrorism Financing Risk Assessment Framework: Southeast Asia and Australia." Counter Terrorist Trends and Analyses 8(10):20-24.

Shust, Pavel M., and Victor Dostov (2020). "Implementing Innovative Customer Due Diligence: Proposal for Universal Model." Journal of Money Laundering Control 23(4):871-84. doi: 10.1108/JMLC-01-2020-0007.

TC00085: Rory Trainor Trading as Best Rate Bureau [2009] UKFTT 117 (TC)

Tofangsaz, Hamed (2015). "Rethinking Terrorist Financing: Where Does All This Lead?" Journal of Money Laundering Control 18(1):112-30. doi: 10.1108/JMLC-12-20130049.

United Nations Convention against Illicit Traffic in Narcotics Drugs and Psychotropic Substances

Vanni, Domitilla (2015). "Amending UN Drug Treaties to Allow Member States SelfDetermination." Journal of Financial Crime 22(4):513-19. doi: 10.1108/JFC-11-20140058 .

W. S. Holdsworth (1918). "The Early History of Banking.” Law Quarterly Review 34(1):1126. 